patients who did not have any other systemic features of the disease.

The high titre antibody to double stranded DNA in case 1 was also helpful in excluding a drug induced lupus syndrome while additional screening for both precipitating antibodies to extractable nuclear antigens ${ }^{4}$ (such as anti-RNP, anti-Ro, anti$\mathrm{La}$ and anti-Sm) and anticardiolipin antibodies might also have been useful. These additional autoantibodies can help to define subsets of the disease (such as the thrombotic tendency associated with anticardiolipin antibodies ${ }^{6}$ ) as well as occasionally being positive when conventional testing for antinuclear antibodies produces negative results.

The improved survival reported in recent series of cerebral SLE has been attributed to earlier diagnosis, more aggressive treatment, and appropriate follow up as well as to the recognition of milder cases. ${ }^{12}$ In our series, although the diagnosis in the first case was delayed for three years, increasing awareness and early immunological screening led to a prompt diagnosis in the other two cases who responded well to vigorous steroid treatment and were left without any residual neurological deficit.

We present these cases to show the varied neurological presentations of cerebral lupus erythematosus and to draw further attention to this condition in childhood. In view of its rarity, we feel it would be useful to set up a national register of cases to monitor progress and treatment of the disorder.

\footnotetext{
References

' Glidden RS, Mantzouranis EC, Borel Y. Lupus erythematosus in childhood: clinical manifestations and improved survival in fifty five patients. Clin Immunol Immunopathol 1983;29: 196-210.

2 Yancey CL, Doughty RA, Athreya BH. Central nervous system involvement in childhood systemic lupus erythematosus. Arthritis Rheum 1981;24:1389-95.

${ }^{3}$ Feinglass EJ, Arnett FC, Dorsh CA. Zizic TM, Stevens MB Neuropsychiatric manifestations of SLE: diagnosis, clinical spectrum and relationship to other features of the disease. Medicine 1976;55:323-39.

+ Reichlin M, Wasicek CA. Clinical and serological differences between systemic lupus erythematosus patients with antibodies to Ro versus patients with antibodies to Ro and La.J Clin Invest 1982;69:835-43.

5 Alarcon-Segovia D. Mixed connective tissue disease-a decade of growing pains. J Rheumatol $1981 ; 8: 535-40$.

${ }^{6}$ Harris EN, Gharavi AE, Hughes GRV. Anti-phospholipid antibodies. Clin Rheum Dis 1985;11:591-609.
}

Correspondence to Dr MF Smith, The Ryegate Children's Centre Tapton Crescent Road. Sheffield S10 5DD.

Accepted 25 February 1988

\title{
Copper in urine and hair in Indian childhood cirrhosis
}

\author{
H R PATEL, ${ }^{*}$ S A BHAVE, A N PANDIT, AND M S TANNER* \\ ${ }^{*}$ Department of Child Health, University of Leicester and Department of Pediatrics, King Edward Memorial \\ Hospital, Pune, India
}

SUMmaRY In advanced Indian childhood cirrhosis (ICC) urine copper concentration was higher (range 416-103 $448 \mathrm{mg} / \mathrm{g}$ creatinine) than in other hepatic diseases (range 67-10 $303 \mathrm{mg} / \mathrm{g}$ creatinine). In early ICC urine copper concentration was more modestly raised (1188-9470 $\mathrm{mg} / \mathrm{g}$ creatinine), but rose to high values (2222-42 $819 \mathrm{mg} / \mathrm{g}$ creatinine) after a single dose of penicillamine $20 \mathrm{mg} / \mathrm{kg}$. A post-penicillamine urinary copper:creatinine ratio $>10000 \mathrm{mg} / \mathrm{g}$ supports a diagnosis of ICC. The concentration of copper in the hair, while increased in advanced ICC, is of no diagnostic value in early cases.

The clinical diagnosis of Indian childhood cirrhosis (ICC) is easy in the late presenting case but is unreliable at an earlier stage. Liver biopsy is therefore necessary. ${ }^{1}$ We sought a robust non- invasive diagnostic method and we have therefore evaluated copper concentrations in urine and hair To obviate the need for 24 hour urine collections, which would not be feasible if the method was to become of value in the field, the copper:creatinine ratio was measured in random samples of urine. The cupriuretic effect of a single dose of penicillamine is of diagnostic value in Wilson's disease ${ }^{2}$ and was studied in ICC and other hepatic disorders.

Hair is painless to collect, easy to store and transport, and provides a historical measure of intracellular copper. Despite well described limitations of hair trace metal analysis, ${ }^{3}$ previous workers have suggested that copper concentration in hair is raised in ICC. ${ }^{4}$

\section{Methods}

Urine was collected from 57 children with ICC and 
from 21 children with other hepatic disorders (table) in Pune. ${ }^{1}$ The children studied were part of a prospective review of liver disease, diagnosis being confirmed by a liver biopsy specimen in each case. Urine was stored at $4^{\circ} \mathrm{C}$ in plastic containers and transported in batches to Leicester.

Eight children (aged 4 to 48 months) with early ICC - that is, without jaundice or ascites-and 15 children (aged 3 to 48 months) with other hepatic disorders (table) had urine collected before and 24 hours after an oral dose of penicillamine $20 \mathrm{mg} / \mathrm{kg}$ body weight.

Urine, with added ammonium nitrate to give a final concentration of $5 \%$ to cause sodium chloride volatisation, was assayed directly for copper by electrothermal atomic absorption spectrophotometry (Pye Unicam SP9).

Containers were shown to be copper free by assaying acid washings. The extent to which containers took up copper from samples $(n=10)$ was found to be insignificant at 0.5 (SD 0.37$) \%$. Repeated assay of an aliquotted urine over a three year period showed good reproducibility $(7.32 \quad(0.95) \mu \mathrm{mol} / \mathrm{l}$ urine). Urinary creatinine concentration was determined colorimetrically. ${ }^{6}$

Hepatic copper concentrations in percutaneous biopsy specimens were assayed as previously described. ${ }^{1}$

Hair was taken from 40 cases of ICC (age 2-48 months); 18 Pune patients with non-hepatic dis- orders (age 10-48 months); and 15 Leicester inpatients (age 1-48 months). Snippings were taken from the crown and the entire length assayed. To remove surface contamination samples were washed with $4 \mathrm{ml}$ acetone followed by $4 \mathrm{ml}$ deionised water and then the washings repeated; each wash took 10 minutes. Samples were dried, weighed, and then digested in $2 \mathrm{ml}$ of $50 \%$ nitric acid at $80^{\circ} \mathrm{C}$ for three hours. After evaporation to dryness samples were redissolved in $2 \mathrm{ml}$ of $0.1 \%$ nitric acid. Copper was assayed as above.

A sample of hair repeatedly assayed gave results of $22.6(9 \cdot 1) \mu \mathrm{g}$ copper/g hair.

Clinical, laboratory, and histological variables were recorded as previously described. ${ }^{1}$ Values for copper:creatinine ratio showed a skewed distribution and were $\log$ transformed for analysis. Groups were compared using Student's unpaired $t$ test.

\section{Results}

The urinary copper:creatinine ratio in 57 children with ICC was significantly greater than that found in 21 children with other hepatic disorders despite the wide scatter results $(p<0 \cdot 001)$. Among children with ICC, more advanced disease was associated with higher copper:creatinine values. Ascites and jaundice are late features of ICC, and cases with neither jaundice nor ascites $(n=15)$ had a copper:creatinine ratio with a significantly lower range (416-39 600,

Table Mean (SD) hepatic copper concentration and urinary copper:creatinine ratio in 57 children (11 girls, 46 boys) with ICC and in 21 children with other hepatic disorders. Urinary copper:creatinine ratio was also assayed in eight children with early ICC and in 15 children with other hepatic disorders before and 24 hours after a single dose of penicillamine $20 \mathrm{mg} / \mathrm{kg}$

\begin{tabular}{|c|c|c|c|c|c|}
\hline & \multirow[t]{2}{*}{$\begin{array}{l}\text { No of } \\
\text { children }\end{array}$} & \multirow{2}{*}{$\begin{array}{l}\text { Hepatic } \\
\text { copper } \\
(\mu g / g d r y \\
\text { weight })\end{array}$} & \multicolumn{3}{|c|}{$\begin{array}{l}\text { Urinary copper:creatinine ratio } \\
\text { (mg copper/g creatinine) }\end{array}$} \\
\hline & & & Median & Range & $\log _{\prime \prime \prime}$ \\
\hline ICC & 57 & $1667(694)$ & 6781 & $416-103448$ & $3.92(0.52) \dagger$ \\
\hline Other hepatic disorders & 21 & $383(373)$ & 452 & $67-10303$ & $2.72(0.58) \dagger$ \\
\hline Chronic active hepatitis & 6 & $498(309)$ & 282 & $75-10303$ & $2.70(0.73)$ \\
\hline Chronic persistent hepatitis & 5 & $162(42 \cdot 8)$ & 245 & $67-3025$ & $2.65(0.70)$ \\
\hline Wilson's disease & 1 & 853 & & & 3.0 \\
\hline Cryptogenic cirrhosis & 1 & 1250 & & & $3 \cdot 0$ \\
\hline Others* & 8 & $219(313)$ & 681 & $77-2000$ & $2.73(0.54)$ \\
\hline \multicolumn{6}{|c|}{ Penicillamine trial } \\
\hline \multicolumn{6}{|c|}{ - son } \\
\hline $\begin{array}{l}\text { Before } \\
24 \text { Hours after }\end{array}$ & 8 & $1342(1037)$ & $\begin{array}{r}4311 \\
28243\end{array}$ & $\begin{array}{l}1188-9470 \\
2222-42819\end{array}$ & $\begin{array}{l}3 \cdot 65(0 \cdot 30) \ddagger \\
4 \cdot 23(0 \cdot 52) \S\end{array}$ \\
\hline \multicolumn{6}{|l|}{ Other hepatic disorders } \\
\hline $\begin{array}{l}\text { Before } \\
24 \text { Hours after }\end{array}$ & 15 & $453(378)$ & $\begin{array}{r}288 \\
4115\end{array}$ & $\begin{array}{r}67-10303 \\
360-33\end{array}$ & $\begin{array}{l}2.74(0.60) \ddagger \\
3.50(0.60) \$\end{array}$ \\
\hline
\end{tabular}

*Other disorders: extrahepatic biliary artresia $(n=2)$, infective hepatitis $(n=2)$, glycogen storage disease $(n=1)$, tuberculosis $(n=1)$, syphilitic hepatitis $(n=1)$, and minor changes $(n=1)$.

$+\mathrm{p}<0.001 ; \neq \mathrm{p}<0.006 ; \S \mathrm{p}<0.001$. 
$\log _{10} 3.7(0.5)$ than those with both jaundice and ascites $\left(1643-91707, \log _{10} 4 \cdot 1 \quad(0 \cdot 5)\right) \quad(\mathrm{p}<0 \cdot 011)$. No correlation existed, however, between the copper:creatinine ratio and serum total or conjugated bilirubin, serum transaminases, or hepatic copper.

In early ICC urine copper concentrations were more modestly raised and showed overlap with those found in other liver disorders even though mean values were significantly different (table).

After a single oral dose of penicillamine $20 \mathrm{mg} / \mathrm{kg}$ a large rise in urinary copper occurred in children with ICC to values exceeding $10000 \mathrm{mg} / \mathrm{g}$ in seven of eight children. A considerably smaller rise occurred in other hepatic disorders, the postpenicillamine value exceeding $10000 \mathrm{mg} / \mathrm{g}$ in only two children. One of these had Wilson's disease and one had chronic active hepatitis (hepatic copper concentrations being 853 and $508 \mu \mathrm{g}$ copper/g dry weight respectively, normal $<100 \mu \mathrm{g} / \mathrm{g}$ ).

Concentrations of copper in the hair of children with ICC (71.9 (55.9), range 13-220) was higher than in the controls from either the United Kingdom $(25.8(14.6)$, range $11-69)$ or India (58.7 (39.7), range 16-170) but the wide scatter of results made these differences non-significant. Children with ICC that was clinically judged to be early had a significantly lower hair copper concentration (19.0 (4.3)) than later $(92.1(86.0))$ or terminal cases $(93.0$ $(53 \cdot 0))$. There was no correlation between hepatic and hair copper.

\section{Discussion}

The present data show that the hepatic copper storage characteristic of ICC is accompanied by greatly raised urine copper:creatinine ratios. In advanced cases values of $10000-93000 \mathrm{mg} / \mathrm{g}$ were found. Absolute concentrations of copper in the urine were $20 \cdot 5-856 \cdot 3 \mu \mathrm{mol} / \mathrm{l}$, concentrations readily detectable by standard chemical assays. Random urine copper is therefore of some diagnostic value, particularly when coagulation defects make liver biopsy hazardous.

It is, however, in the early case that non-invasive diagnostic methods are more urgently required. The present study shows that in ICC that has not progressed to the development of ascites or jaundice urinary copper:creatinine ratios are modestly raised and do not provide a clear distinction from other hepatic disorders. After a single dose of penicillamine $20 \mathrm{mg} / \mathrm{kg}$, however, the ratio sharply increased. Values exceeded $10000 \mathrm{mg}$ copper/g creatinine in seven out of eight cases. Other disorders associated with raised hepatic copper show a modest post-penicillamine cupriuresis. The other important cause of raised urine copper in infancy, extrahepatic biliary atresia, is clinically quite distinct from ICC, however, while Wilson's disease is rarely symptomatic before 5 years of age, and may be differentiated from ICC by serum caeruloplasmin assay.

Hair copper concentrations are raised in advanced ICC confirming previous reports, ${ }^{45}$ but the diagnostic value of this is limited because of the variation in normal values. Exogenous copper contamination contributes to this variation despite meticulous sample preparation. ${ }^{7}$ The difference between the controls in the United Kingdom and India may reflect different use of oily scalp preparations or may genuinely reflect copper status. Another disadvantage is that hair copper concentration is normal in the early case in which diagnosis is most difficult.

We conclude that random urine and hair copper concentrations are raised in advanced ICC. While hair copper is of no diagnostic value in early ICC a post-penicillamine urine copper:creatinine ratio greater than $10000 \mathrm{mg} / \mathrm{g}$ is highly suggestive of the diagnosis.

We gratefully acknowledge support from the Wellcome Trust and thank Mrs A Gilbert for typing the manuscript.

\section{References}

1 Bhave SA, Pandit AN, Pradhan AM, et al. Liver disease in India. Arch Dis Child 1982;57:922-8.

2 Sass-Kortsak A, Bearn AG. Hereditary disorders of copper metabolism. In: Stanbury JB, Wyngaarden JB, Frederickson DS, eds. The metabolic basis of inherited disease. New York: McGraw Hill, 1978:1098-126.

3 Manson P, Zlotkin S. Hair analysis-a critical revicw. Can Med Assoc J 1985;133:186-8.

+ Sharda B, Bhandari B. Copper concentration in plasma, cells, liver, urine, hair and nails in hepatobiliary disorders in children. Indian Pediatr 1984;21:167-71.

5 Misra PK. Chawla AC, Srivastava KL, Waklu I, Mehrotra R. Hair copper in Indian childhood cirrhosis. Indian Pediatr 1985:22:117-9.

" Grafnetter D, Janosova Z, Ccrinkova I. Note on Slot's method for the specific determination of creatininc. Clin Chim Acta 1967;17:493-8.

${ }^{7}$ Clanet P. DeAntonio SM, Katz SA, Schncincr DM. Effects of some cosmetics on copper and zinc concentrations in human scalp hair. Clin Chem 1982;28:245()-1.

Correspondence to Dr MS Tanner, Department of Child Health, Clinical Sciences Building, PO Box 65, Leicester Royal Infirmary, Lcicester LE2 7LX.

Accepted 25 February 1988 